\title{
Protective effect of dietary nitrate on experimental gastritis in rats
}

\author{
Muriel Larauche ${ }^{1}$, Pauline M. Anton ${ }^{1}$, Rafaël Garcia-Villar ${ }^{1}$, Vassilia Theodorou ${ }^{2}$, Jacques Frexinos ${ }^{3}$, \\ Lionel Buéno ${ }^{1}$ and Jean Fioramonti ${ }^{1} *$ \\ ${ }^{1}$ Neuro-Gastroenterology and Nutrition Unit, Institut National de la Recherche Agronomique, \\ 180 chemin de Tournefeuille, BP3, 31931 Toulouse cedex 9, France \\ ${ }^{2}$ Department of Physiology, Ecole Supérieure d'Agriculture de Purpan, Toulouse, France \\ ${ }^{3}$ Department of Gastroenterology, Rangueil Hospital, Toulouse, France
}

(Received 6 June 2002 - Revised 10 December 2002 - Accepted 19 January 2003)

\begin{abstract}
Nitrates have long been considered as harmful dietary components and judged responsible for deleterious effects on human health, leading to stringent regulations concerning their levels in food and water. However, recent studies demonstrate that dietary nitrate may have a major role in human health as a non-immune mechanism for host defence, through its metabolism to NO in the stomach. NO is a versatile molecule and although evidence exists showing that administration of low doses of exogenous NO protects against gastrointestinal inflammation, higher NO doses have been shown to exacerbate injury. So, the effect of an ingestion of nitrates in doses corresponding to a normal diet in human consumers on an experimental gastritis induced by iodoacetamide in rats was investigated. During gastritis one of the following compounds was given orally: water; $\mathrm{KNO}_{3}$; the $\mathrm{NO}$ donor sodium nitroprusside; the $\mathrm{NO}$ scavenger haemoglobin given with either water or $\mathrm{KNO}_{3}$. $\mathrm{N}(\mathrm{G})$-nitro-L-arginine methyl ester (L-NAME), a non-specific NO synthase inhibitor, was administered with either water, iodoacetamide alone, or combined with $\mathrm{KNO}_{3}$. After killing, the stomach was resected and microscopic damage scores, myeloperoxidase and NO synthase activities were determined. Iodoacetamide-induced gastritis was significantly reduced by $\mathrm{KNO}_{3}$ administration, an effect which was reproduced by sodium nitroprusside and reversed by haemoglobin. L-NAME induced gastric mucosal damage in itself, and $\mathrm{KNO}_{3}$ did not prevent the gastritis induced by iodoacetamide associated with L-NAME. In conclusion, dietary nitrate exerts a protective effect against an experimental gastritis in rats by releasing NO in the stomach but such an effect requires the production of endogenous NO.
\end{abstract}

Nitric oxide: Inflammation: Dietary nitrate: Stomach

The human diet is a source of direct (natural components) and indirect (additives, pesticides, etc) factors which are able to modulate gastrointestinal functions. Among these potentially modulating dietary factors, nitrates occupy a controversial position. The main sources of nitrates for human consumers are green and leafy vegetables, drinking water and also some meat and fish products where nitrates are widely used as preservatives in the form of $\mathrm{Na}$ and $\mathrm{K}$ salts. The total dietary intake of nitrates, excluding nitrates in the water, has been estimated as $50-80 \mathrm{mg} / \mathrm{d}$ per person (Meah et al. 1994; Dich et al. 1996). When ingested, dietary nitrate is absorbed from the stomach and proximal intestine into the plasma and then concentrated in saliva (Tannenbaum et al. 1976), where it is rapidly reduced to nitrites by anaerobic bacteria (Spiegelhalder et al. 1976; Walters \& Smith, 1981). The two potentially deleterious effects of high gastric concentrations of nitrates are methaemoglobinaemia (Craun et al. 1981) and formation of carcinogenic N-nitroso compounds (Bruning-Fann \& Kaneene, 1993). However, beyond these potential effects, nitrites are transformed into NO under the acidic conditions of the stomach (Benjamin et al. 1994; Duncan et al. 1995), an event that has been shown to participate in the protection of the organism against pathogen-induced

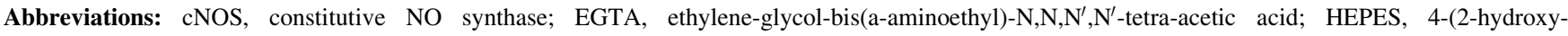
ethyl)piperazine-1-ethanesulfonic acid; iNOS, inducible NO synthase; L-NAME, N(G)-nitro-L-arginine methyl ester; MPO, myeloperoxidase; NOS, nitric oxide synthase; SNP, sodium nitroprusside.

* Corresponding author: Dr J. Fioramonti, fax +33 561285 145, email jfioramo@toulouse.inra.fr
} 
gastrointestinal and oral diseases (Green, 1995; Dykhuizen et al. 1996; Duncan et al. 1997). In human subjects, ingestion of small amounts of nitrates (i.e. $2 \mathrm{mmol}$ which corresponds to the amount normally found in a lettuce; Meah et al. 1994) has thus been found to generate high concentrations of $\mathrm{NO}$ in the stomach (McKnight et al. 1997).

Gastric NO may not be delivered only by extrinsic sources, but may also be generated by mucosal cells, which are able to produce large amounts of NO (Konturek \& Konturek, 1995). Indeed, endogenous NO is produced from the amino acid L-arginine by either constitutive NO synthase (cNOS) or inducible NO synthase (iNOS) (Moncada et al. 1991) and both NOS have been detected in homogenates of rat gastric mucosa (Tepperman \& Soper, 1994). In physiological conditions, cNOS is the only one expressed in gastric mucosa where it plays an important role in the maintenance of mucosal integrity. In contrast, iNOS, which is induced by bacterial lipopolysaccharide or cytokines such as interleukin- 1 and tumournecrosis factor-a, produces large amounts of NO which are considered detrimental to the gastric mucosa (Brown et al. 1994) and have been found involved in the process of gastric inflammation in man as in rats (Rachmilewitz et al. 1994; Nishida et al. 1998). However, controversy still exists concerning the deleterious effects of iNOSproduced NO (Wei et al. 1995; McCafferty et al. 1997; Akiba et al. 1998).

Even though the effects of endogenous NO on gastrointestinal inflammation are discussed, there is substantial evidence that intragastric topical application of NO-releasing substances protects the gastric mucosa from damage induced by injurious agents (MacNaughton et al. 1989; Kitagawa et al. 1990). Nevertheless, this protective effect is dose-sensitive as high doses of exogenous NO can lead to gastric mucosal injury (Lopez-Belmonte et al. 1993; Lamarque \& Whittle, 1995; Gurbuz et al. 1999) similar to what has been previously reported for endogenous NO (Brown et al. 1994).

Thus, considering nitrate daily consumption, controversial effects on human health as well as potentiality to induce the release of consequent quantities of $\mathrm{NO}$ in the stomach, and the debated role of NO in the modulation of gastric mucosal inflammation, the present study was designed to determine the effects of chronic ingestion of nitrates, in amounts that can be found in our normal daily diet, on an experimentally induced gastritis in rats.

\section{Materials and methods}

\section{Animals}

Male Wistar rats (Harlan, Gannat, France) weighing between 200 and $250 \mathrm{~g}$ at the time of the experiments were housed in polypropylene cages in a temperature-controlled room $\left(21 \pm 1^{\circ} \mathrm{C}\right)$ under controlled lighting. They were allowed free access to water and were fed during the night (19.00 to 9.00 hours) with a standard diet (A04; UAR, Epinay-sur-Orge). All protocols were approved by the local Institutional Animal Care and Use Committee.

\section{Effect of potassium nitrate treatment on iodoacetamide- induced gastritis: role of nitric oxide}

Fourteen groups of eight rats were treated for $7 \mathrm{~d}$ (Table 1). Solutions were administered intragastrically using a gastric feeding tube, except where otherwise indicated. The effects of $\mathrm{KNO}_{3}$ administration on iodoacetamide-induced gastritis were investigated in groups 1 to 4 . With this end in view, rats received iodoacetamide $(25 \mathrm{mg} / \mathrm{kg}$ per d) or distilled water associated (groups 2 and 4) or not (groups 1 and 3) with $\mathrm{KNO}_{3}(125 \mathrm{mg} / \mathrm{kg}$ twice daily). The dose of iodoacetamide used was selected from previous dose-response studies (M Larauche, P Anton, L Buéno and J Fioramonti, unpublished results). Administration of iodoacetamide was performed for the duration of $7 \mathrm{~d}$ according to Karmeli et al. (1996) who showed a maximum increase in gastric myeloperoxidase (MPO) activity and lesions for this period of administration. Groups 5 to 9 were used to assess the involvement of $\mathrm{NO}$ in the protective effect of $\mathrm{KNO}_{3}$ against iodoacetamide-induced gastritis. First, groups 5 and 6 , respectively received an NO donor, sodium nitroprusside (SNP; $0.7 \mathrm{mg} / \mathrm{kg}$ three times daily) associated or not with iodoacetamide. The dose of SNP used was selected from previous dose-response studies showing the near-maximum inhibition of iodoacetamideinduced gastric mucosal damage (M Larauche, P Anton, $\mathrm{L}$ Buéno and $\mathrm{J}$ Fioramonti, unpublished results). The three other groups received the NO scavenger, haemoglobin $(75 \mathrm{mg} / \mathrm{kg}$ twice daily), with either distilled water (group 7), iodoacetamide (group 8), or $\mathrm{KNO}_{3}$ and iodoacetamide (group 9). Finally, the last four groups (10 to 14) were used to investigate the interrelationships existing between endogenous gastric $\mathrm{NO}$ and exogenous $\mathrm{NO}$ brought in by $\mathrm{KNO}_{3}$. Thus, rats received a non-specific inhibitor of NOS, N(G)-nitro-L-arginine methyl ester (L-NAME; $10 \mathrm{mg} / \mathrm{kg}$ per $\mathrm{d}$, intraperitoneally), either $30 \mathrm{~min}$ before distilled water (group 10), iodoacetamide (group 11), or iodoacetamide and $\mathrm{KNO}_{3}$ (group 12), or just 5 min after L-arginine or D-arginine $(300 \mathrm{mg} / \mathrm{kg}$ per d, subcutaneously; groups 13 and 14 respectively). The doses of haemoglobin and L-NAME used were in agreement with previous in vivo studies (Fargeas et al. 1996; Rouzade et al. 1999). Rats were killed $8 \mathrm{~d}$ after the beginning of

Table 1. Treatments performed in the fourteen groups of rats

\begin{tabular}{ll}
\hline Group number & \multicolumn{1}{c}{ Treatment } \\
\hline 1 & Water \\
2 & Water+ $\mathrm{KNO}_{3}$ \\
3 & lodoacetamide \\
4 & lodoacetamide+ $\mathrm{KNO}_{3}$ \\
5 & Water+ sodium nitroprusside \\
6 & lodoacetamide+ sodium nitroprusside \\
7 & Water+haemoglobin \\
8 & lodoacetamide+haemoglobin \\
9 & lodoacetamide+haemoglobin+ $\mathrm{KNO}_{3}$ \\
10 & L-NAME+ water \\
11 & L-NAME+ iodoacetamide \\
12 & L-NAME+ iodoacetamide+ $\mathrm{KNO}_{3}$ \\
13 & L-arginine+L-NAME \\
14 & D-arginine+ L-NAME \\
\hline
\end{tabular}


treatments. The stomachs were isolated, removed, and washed with saline $(9 \mathrm{~g} \mathrm{NaCl} / \mathrm{l})$. Segments $(20 \mathrm{~mm})$ of the stomach (antrum) were taken off in order to determine MPO and NOS activities and identify histological lesions. Tissues collected for MPO and NOS assays were stored at $-80^{\circ} \mathrm{C}$ until determination.

\section{Collection of plasma and saliva in rats}

Two groups of seven rats weighing 200-250 g at the time of the experiment were used. One group received $0.5 \mathrm{ml}$ distilled water intragastrically and the other received $0.5 \mathrm{ml}$ of $\mathrm{KNO}_{3}$ at the dose of $125 \mathrm{mg} / \mathrm{kg}$. At $30 \mathrm{~min}$ after oral administration, rats were anaesthetized using acepromazine $(0.6 \mathrm{mg} / \mathrm{kg}$ intraperitoneally) and ketamine $(120 \mathrm{mg} / \mathrm{kg}$ intraperitoneally). At $5 \mathrm{~min}$ after anaesthesia, rats received an injection of pilocarpine hydrochloride $(0.5 \mathrm{mg} / \mathrm{kg}$ intraperitoneally, $0.2 \mathrm{ml})$. After $5-10 \mathrm{~min}$, whole mixed saliva samples $(250 \mu \mathrm{l})$ were drawn, and $500 \mu \mathrm{l}$ of a TCA solution $(25 \%$, v/v) were added. Samples were vigorously vortexed and centrifuged at $3000 \mathrm{~g}$ for $15 \mathrm{~min}$ at $4^{\circ} \mathrm{C}$. Pellets were discarded and supernatant fractions were stored at $-20^{\circ} \mathrm{C}$ until determination. After saliva collection, 50-60 min after oral administration, the rats' body wall and peritoneum at the ventral midline were incised in order to perform needle puncture in the abdominal aorta. Thus, $1.8 \mathrm{ml}$ of blood was collected using a plastic syringe filled with $0.2 \mathrm{ml}$ of anticoagulant $(3.8 \%(\mathrm{w} / \mathrm{v})$ sodium citrate). Immediately after collection, whole blood was centrifuged at $800 \mathrm{~g}$ for $15 \mathrm{~min}$ at $4^{\circ} \mathrm{C}$, and citrated plasma was drawn. In the same way as for saliva, $500 \mu$ l of a TCA solution $(25 \%$, v/v) was added to $250 \mu \mathrm{l}$ citrated plasma. Samples were then vigorously vortexed and centrifuged at $3000 \mathrm{~g}$ for $15 \mathrm{~min}$ at $4^{\circ} \mathrm{C}$. Pellets were discarded and supernatant fractions were stored at $-80^{\circ} \mathrm{C}$ until assay.

\section{Morphological studies}

Pieces of stomach (20 mm long) were fixed in Carnoy's solution, cleared in xylene and embedded in paraffin blocks. Transverse sections $(5 \mu \mathrm{m})$ were cut and stained with haematoxylin and eosin, and examined by light microscopy in a blind manner. A histological grading scale (microscopic damage score) was used for the determination of the extent of the inflammatory reaction in the gastric mucosa (Fabia et al. 1993). Each of the individual variables estimated was graded from 0 to 3 , according to the severity of the alterations. The variables were: ulceration; mucosal atrophy; oedema; inflammatory cell infiltration; vascular dilatation.

\section{Myeloperoxidase activity assay}

The activity of the enzyme MPO, a marker of polymorphonuclear neutrophil primary granules, was determined in gastric tissue according to a previously described technique (Bradley et al. 1982). Segments of stomach were suspended in a potassium phosphate buffer $\left(44 \mathrm{mM}-\mathrm{KH}_{2} \mathrm{PO}_{4}\right.$, 6 mM- $\mathrm{K}_{2} \mathrm{HPO}_{4} .3 \mathrm{H}_{2} \mathrm{O} ; \mathrm{pH} 6.0$ ) and homogenized on ice using a Polytron (PCU-2; Kinematica $\mathrm{GmbH}$, Lucerne,
Switzerland), and followed by three cycles of freezing and thawing. Suspensions were then centrifuged at $9000 \mathrm{~g}$ for $15 \mathrm{~min}$ at $4^{\circ} \mathrm{C}$. Supernatant fractions were discarded and pellets were resuspended in hexadecyl trimethylammonium bromide buffer $(0.5 \%$ (w/v) in the potassium phosphate buffer), a detergent inducing the release of MPO from polymorphonuclear neutrophil primary granules. These suspensions were sonicated on ice (Büchi, Flawil, Switzerland), and again centrifuged at $9000 \mathrm{~g}$ for $15 \mathrm{~min}$ at $4^{\circ} \mathrm{C}$. Pellets were discarded and supernatant fractions assayed spectrophotometrically for MPO activity and protein contents. Supernatant fractions obtained were diluted in the potassium phosphate buffer containing $0.167 \mathrm{mg}$ $o$-dianisidine dihydrochloride/ml and $0.0005 \%(\mathrm{v} / \mathrm{v})$ $\mathrm{H}_{2} \mathrm{O}_{2}$. MPO from human neutrophils (Sigma, Saint Quentin Fallavier, France; 0.1 U/100 $\mu \mathrm{l}$ ) was used as a standard. Changes in absorbance at $450 \mathrm{~nm}$ were recorded with a spectrophotometer (Uvikon 922; Kontron Instruments, Saint Quentin en Yvelines, France) every 10 s over 2 min. One unit of MPO activity was defined as the quantity of MPO degrading $1 \mu \mathrm{mol} \mathrm{H}_{2} \mathrm{O}_{2} / \mathrm{min}$ per $\mathrm{ml}$ at $25^{\circ} \mathrm{C}$. Protein concentrations $(\mathrm{g} / \mathrm{ml})$ were determined with a commercial kit of the modified method of Lowry (Detergent Compatible Assay; Bio Rad, Ivry/Seine, France), and MPO activity was expressed as MPO units/g protein.

\section{Determination of nitric oxide synthase activity}

Tissue NOS activities were estimated by measuring the rate of conversion of $\mathrm{L}-\left[{ }^{14} \mathrm{C}\right]$ arginine to $\mathrm{L}-\left[{ }^{14} \mathrm{C}\right]$ citrulline (Bush et al. 1992). Tissue samples were homogenized on ice in a buffer ( $\mathrm{pH} 7 \cdot 4)$ containing Tris-HCl (50 mM), dithiothreitol (1 mM), phenylmethylsulfonylfluoride (1 mM), EDTA (0.1 mM) and two protease inhibitors: leupeptin $(23.4 \mu \mathrm{M})$ and pepstatin $(14.6 \mu \mathrm{M})$. After centrifugation $\left(13500 \mathrm{~g}, 30 \mathrm{~min}, 4^{\circ} \mathrm{C}\right), 100 \mu \mathrm{l}$ of supernatant fraction was added to a reaction mixture containing $50 \mathrm{mM}-\mathrm{Tris}-\mathrm{HCl} \quad(\mathrm{pH} \quad 7.4), \quad 1.58 \mu \mathrm{M}-\mathrm{L}-\left[{ }^{14} \mathrm{C}\right]$ arginine, $200 \mu \mathrm{M}-\mathrm{NADPH}$ as a co-substrate, $10 \mu \mathrm{M}-\mathrm{FMN}$, and $10 \mu \mathrm{M}-\mathrm{FAD}$ as prosthetic groups of NOS, $1 \mathrm{mM}$-tetrahydrobiopterine, $1 \mathrm{~mm}$-dithiothreitol and $50 \mathrm{~mm}$-valine. Determination of total NOS activity was performed by adding $2 \mathrm{mM}-\mathrm{CaCl}_{2}$. iNOS activity was determined in the presence of a $\mathrm{Ca}$ chelator, ethylene-glycol-bis(a-aminoethyl)$\mathrm{N}, \mathrm{N}, \mathrm{N}^{\prime}, \mathrm{N}^{\prime}$-tetra-acetic acid (EGTA; $\left.1 \mathrm{mM}\right)$. cNOS activity was determined by the difference between both activities. After $30 \mathrm{~min}$ incubation at $37^{\circ} \mathrm{C}$, the enzymic reaction was stopped by adding cold 4-(2-hydroxyethyl)piperazine-1-ethanesulfonic acid (HEPES) buffer (pH 5.5) containing $1 \mathrm{mM}$-EGTA and $1 \mathrm{mM}$-EDTA. L- $\left[{ }^{14} \mathrm{C}\right]$ citrulline formed in the medium was separated by applying the samples to columns containing pre-equilibrated Dowex AG50W-X8, eluting them with water, and measuring the amount of radioactivity with a liquid scintillation Beta counter (Kontron Instruments, St Quentin en Yvelines, France). Protein concentrations $(\mathrm{mg} / \mathrm{ml})$ were determined with a commercial kit of the modified method of Lowry (Detergent Compatible Assay; Bio Rad, Ivry/Seine, France) Enzyme activity was expressed as pmol citrulline formed/mg protein per $h$. 


\section{Nitrate and nitrite assays}

The levels of nitrates and nitrites were determined in rats' saliva and plasma according to the method of Griess (Grisham et al. 1995). Briefly, a $100 \mu l$ portion of a sample (saliva or citrated plasma) was incubated for $30 \mathrm{~min}$ at $37^{\circ} \mathrm{C}$ with $50 \mathrm{mM}$-HEPES buffer, $5 \mu \mathrm{M}-\mathrm{FAD}$ and $0 \cdot 1 \mathrm{mM}-\mathrm{NADPH}$ in a total volume of $500 \mu \mathrm{l}$ in the presence (nitrites+nitrates levels) or not (nitrites level) of 0.2 units nitrate reductase $/ \mathrm{ml}$ from Aspergillus species. Following the incubation, $5 \mu \mathrm{l}$ of lactic dehydrogenase (1500 units/ml) and $50 \mu \mathrm{l}$ of $100 \mathrm{~mm}$-pyruvic acid were added to each tube to oxidize unreacted NADPH. Samples were then incubated for an additional $10 \mathrm{~min}$ at $37^{\circ} \mathrm{C}$. Premixed Griess reagent $(1 \mathrm{ml}) \quad(0 \cdot 2 \% \quad(\mathrm{w} / \mathrm{v})$ naphtylethylenediamine $+2 \% \quad(\mathrm{w} / \mathrm{v})$ sulfanilamide in $5 \%(\mathrm{w} / \mathrm{v})$ phosphoric acid) was then added to each tube and after $10 \mathrm{~min}$ incubation at room temperature the absorbance of each sample was determined at $543 \mathrm{~nm}$ with a spectrophotometer (Uvikon 922; Kontron Instruments, St Quentin en Yvelines, France). $\mathrm{NaNO}_{3}(1 \mathrm{mM})$ and $\mathrm{NaNO}_{2}(1 \mathrm{mM})$ solutions were used as standards. The detection limit of the assay was $1.92 \mu \mathrm{M}$ and the quantification limit was $6.41 \mu \mathrm{M}$.

\section{Chemicals}

Iodoacetamide, $\mathrm{KNO}_{3}$, SNP, haemoglobin, L-NAME, L-arginine hydrochloride, D-arginine hydrochloride, Dowex AG50W-X8 ( $\mathrm{H}^{+}$form) 100-200 mesh, valine, NADPH, dithiothreitol, phenylmethylsulfonylfluoride, EDTA, EGTA, leupeptin, pepstatin, FMN, $\mathrm{FAD}, \mathrm{CaCl}_{2}$, $\mathrm{KH}_{2} \mathrm{PO}_{4}, \mathrm{~K}_{2} \mathrm{HPO}_{4} .3 \mathrm{H}_{2} \mathrm{O}$, hexadecyl trimethyl ammonium bromide, $\mathrm{H}_{2} \mathrm{O}_{2}, \quad o$-dianisidine hydrochloride, lactic dehydrogenase from bovine muscle, $\mathrm{NaNO}_{3}, \mathrm{NaNO}_{2}$, naphtylethylenediamine, sulfanilamide, and HEPES and Tris- $\mathrm{HCl}$ buffers were purchased from Sigma, Saint Quentin Fallavier, France. L- $\left[{ }^{14} \mathrm{C}\right]$ arginine was purchased from ICN Biomedicals, Orsay, France. Nitrate reductase from Aspergillus species was purchased from Roche Diagnostic Biochemicals, Meylan, France. Phosphoric acid (85\%, w/v) was purchased from Carlo Erba Reactifs, Val de Reuil, France. Solutions used for oral treatments were prepared in distilled water.

\section{Statistical analysis}

MPO activity, NOS activity and histological data were analysed by ANOVA followed by Tukey's post hoc test for multiple comparisons using GraphPad Prism version 3.00 for Windows (GraphPad Software, San Diego, CA). Saliva and plasma nitrates and nitrites levels were analysed by using Student's $t$ test for unpaired values using GraphPad Prism version 3.00 for Windows (GraphPad Software, San Diego, CA). Results are expressed as means and standard errors of the mean, and differences were considered significant at $P<0.05$.

\section{Results \\ Iodoacetamide-induced gastritis in rats}

Iodoacetamide administration for $7 \mathrm{~d}$ induced gastric mucosal damage characterized by a significant increase of tissue MPO activity (3112 (SEM 180) v. 1206 (SEM 134) MPO units/g protein in controls; $P<0.05$ ). Histologically, oedema was found in the submucosa, with vascular dilatation and a mild inflammatory cell infiltrate leading to a significant increase in microscopic damage scores (4.56 (SEM 0.50) v. 1.30 (SEM 0.30) units for the control group; $P<0.05$ ) (Fig. 1). Iodoacetamide significantly increased cNOS activity (125 (SEM 17) v. 55 (SEM 6) $\mathrm{pmol} / \mathrm{mg}$ protein per $\mathrm{h} ; P<0.05)$ but did not modify iNOS activity (Fig. 2).

\section{Effect of potassium nitrate treatment on iodoacetamide-induced gastritis}

Treatment with $\mathrm{KNO}_{3}$ suppressed the iodoacetamideinduced increase in gastric MPO activity and in microscopic damage score (1542 (SEM 123) MPO units/g protein and 1.83 (SEM 0.54) units, respectively) (Fig. 1). The increase
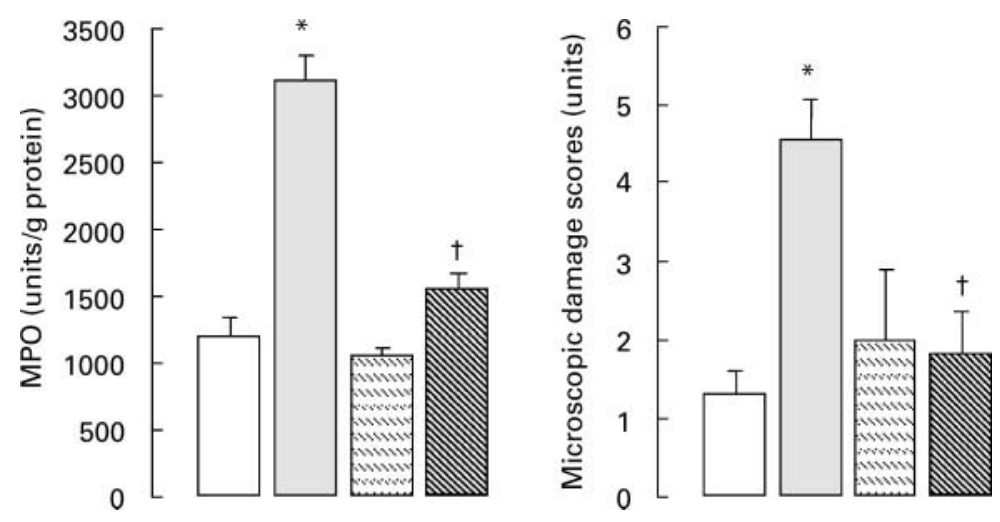

Fig. 1. Effect of $\mathrm{KNO}_{3}$ on gastric microscopic damage scores and myeloperoxidase (MPO) activity in iodoacetamide-induced gastritis in rats. Mean values for eight rats per group are shown, with standard errors of the mean being represented by vertical bars. * Mean values were significantly different from that of the control group $(P<0.05)$. $†$ Mean values were significantly different from that of the group treated with iodoacetamide alone $(P<0 \cdot 05)$. ( $\square$ ), Control group; $\square$, iodoacetamide-treated group; ( $\Xi), \mathrm{KNO}_{3}$-treated group; ( $\mathbb{\mathbb { N }}$ ), $\mathrm{KNO}_{3}+$ iodoacetamidetreated group. 

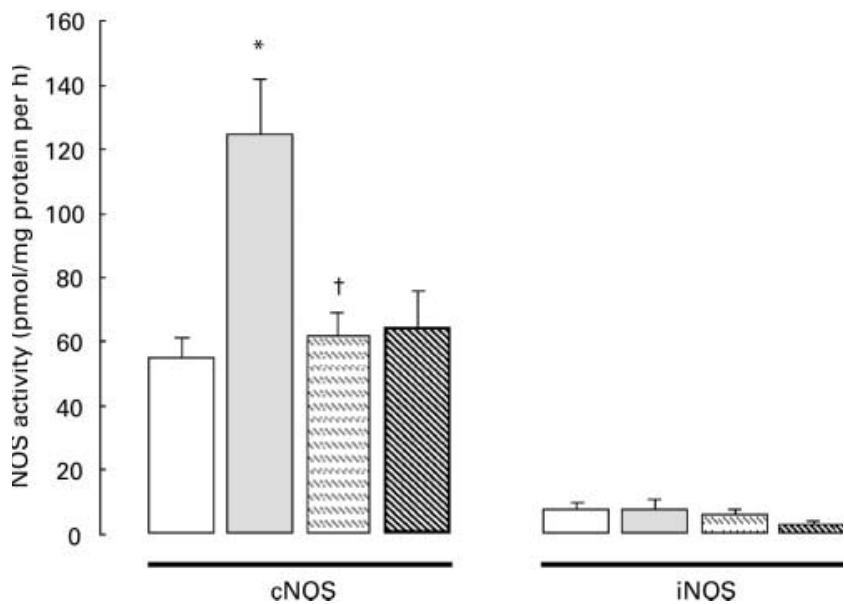

Fig. 2. Effect of $\mathrm{KNO}_{3}$ on gastric constitutive $\mathrm{NO}$ synthase (cNOS) and inducible NO synthase (iNOS) activities in iodoacetamideinduced gastritis in rats. Mean values for five to eleven rats per group are shown, with standard errors of the mean being represented by vertical bars. * Mean value was significantly different from that of the control group $(P<0.05)$. † Mean value was significantly different from that of the group treated with iodoacetamide alone $(P<0.05)$. ( $\square)$, Control group; $(\square)$, iodoacetamide-treated

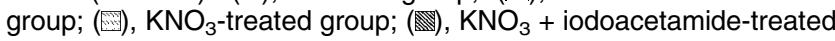
group.

in cNOS activity induced by iodoacetamide was abolished by $\mathrm{KNO}_{3}$ treatment (Fig. 2).

\section{Effect of potassium nitrate treatment on nitrates and nitrites levels in plasma and saliva}

In control rats, nitrate levels in plasma and saliva were 7 (SEM 2) and 13 (SEM 4) $\mu \mathrm{M}$, respectively. Intragastric administration of $\mathrm{KNO}_{3}$ significantly increased nitrate levels in plasma and saliva compared with control rats (342 (SEM 13) and 336 (SEM 4) $\mu$ M, respectively) (Fig. 3). Nitrites were undetectable in all samples except in the saliva of all rats treated with $\mathrm{KNO}_{3}$ where trace amounts below the detection limit of the method were observed.

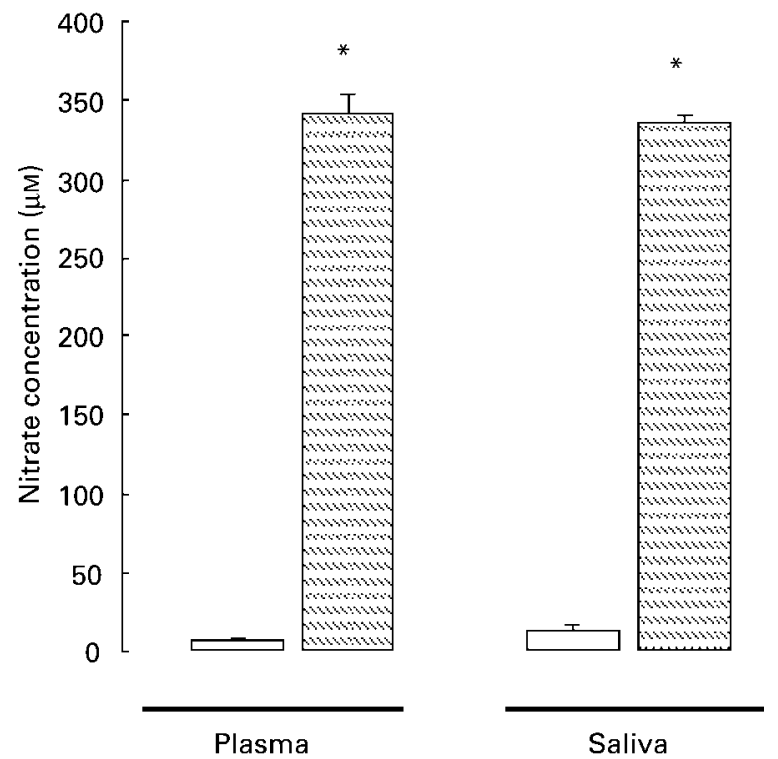

Fig. 3. Effect of $\mathrm{KNO}_{3}$ on nitrate in the plasma and saliva of rats. Mean values for seven rats per group are shown, with standard errors of the mean being represented by vertical bars. * Mean values were significantly different from that of the control group $(P<0 \cdot 05)$. ( $\square)$, Control group; ( $\left.{ }^{\circ}\right), \mathrm{KNO}_{3}$-treated group.

Involvement of nitric oxide in the protective effect of potassium nitrate against iodoacetamide-induced gastritis

Treatment with the NO donor, SNP, suppressed the increase in gastric MPO activity and microscopic damage score induced by iodoacetamide (1818 (SEM 200) MPO units/g protein and 2.57 (SEM 0.81) units, respectively) (Fig. 4). Treatment with $\mathrm{KNO}_{3}$ suppressed the iodoacetamide-induced increase in gastric MPO activity and microscopic damage scores, but the co-administration of haemoglobin with $\mathrm{KNO}_{3}$ restored the increase in gastric MPO activity and damage scores induced by iodoacetamide (Fig. 5). Haemoglobin alone did not modify iodoacetamide-induced gastritis.
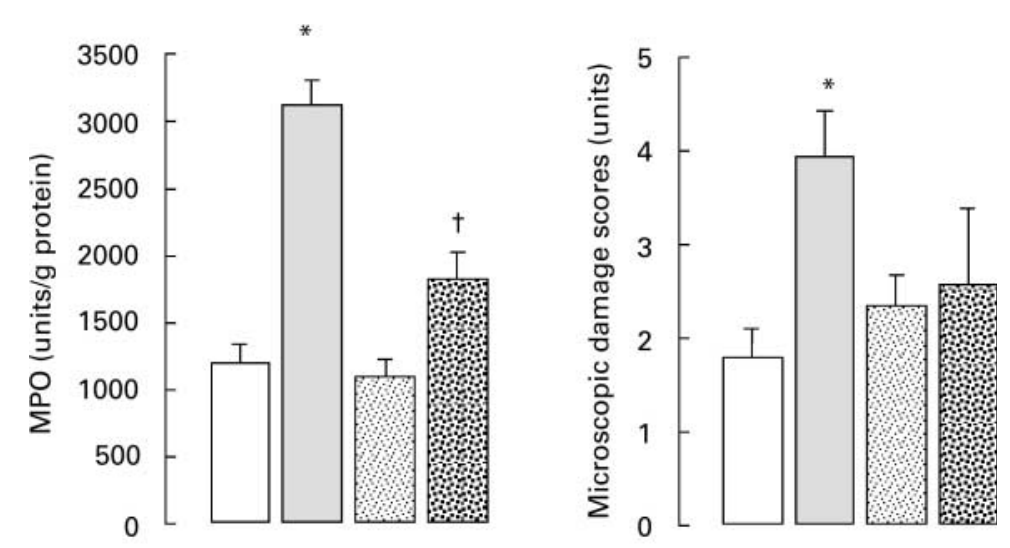

Fig. 4. Effect of sodium nitroprusside on gastric microscopic damage scores and myeloperoxidase (MPO) activity in iodoacetamide-induced gastritis in rats. Mean values for eight rats per group are shown, with standard errors of the mean being represented by vertical bars. ${ }^{*}$ Mean values were significantly different from that of the control group $(P<0.05)$. † Mean value was significantly different from that of the group treated with iodoacetamide alone $(P<0 \cdot 05)$. ( $\square$ ), Control group; ( $\square$ ), iodoacetamide-treated group; (圆), sodium nitroprusside-treated group; (關), sodium nitroprusside+iodoacetamide-treated group. 

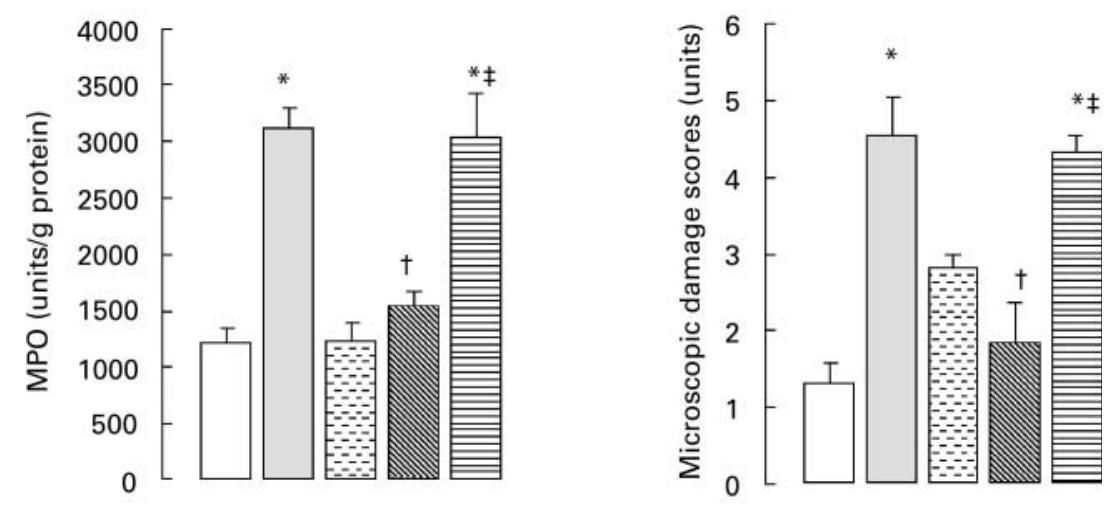

Fig. 5. Influence of haemoglobin on gastric microscopic damage scores and myeloperoxidase (MPO) activity in iodoacetamide-induced gastritis in rats treated with $\mathrm{KNO}_{3}$. Mean values for eight rats per group are shown, with standard errors of the mean being represented by vertical bars. * Mean values were significantly different from that of the control group $(P<0.05)$. $\dagger$ Mean values were significantly different from that of the group treated with iodoacetamide alone $(P<0.05)$. $¥$ Mean values were significantly different from that of the group treated with $\mathrm{KNO}_{3}+$ iodoacetamide $(P<0.05)$. ( $\square)$, Control group; $\square$ ), iodoacetamide-treated group; (圈), haemoglobin-treated group; ( $\left(\mathbb{M N O}_{3}+\mathrm{KNO}_{3}+\right.$ iodocetamidetreated group; (目), $\mathrm{KNO}_{3}+$ iodoacetamide + haemoglobin-treated group.

\section{Interaction between exogenous and endogenous nitric oxide in iodoacetamide-induced gastritis}

Repeated administrations of L-NAME once daily for $7 \mathrm{~d}$ caused a significant increase in gastric MPO activity (2766 (SEM 258) v. 1206 (SEM 134) MPO units/g protein in controls; $P<0.05)$. This treatment tended to increase the microscopic damage scores (3.29 (SEM 0.18) v. 1.30 (SEM 0.30) units for the control group) but the significance level of $P<0.05$ was not attained (Fig. 6). This effect of L-NAME on gastric MPO activity was antagonized by co-administration of L-arginine (1107 (SEM 106) v. 2766 (SEM 258) MPO units/g protein for the L-NAME-treated group; $P<0.05)$ but not by $\mathrm{D}$-arginine (2356 (SEM 573) v. 2766 (SEM 258) MPO units/g protein for the L-NAME-treated group).

The co-administration of L-NAME with iodoacetamide induced greater gastric MPO activity than L-NAME given alone (4066 (SEM 543) v. 2766 (SEM 258) MPO units/g protein for the L-NAME-treated group) and tended to increase the microscopic damage score (5.5 (SEM 0.5) v. $3 \cdot 29$ (SEM 0.18) units for the L-NAME-treated group). Treatment with $\mathrm{KNO}_{3}$ did not prevent the L-NAME-induced aggravation of the gastritis induced by iodoacetamide (Fig. 6).

\section{Discussion}

It has been suggested for many years that dietary nitrates were potentially harmful for human health because of their ability to form nitrites and carcinogenic compounds in the stomach (Bruning-Fann \& Kaneene, 1993). It has only recently been found that nitrates may play a key role in the mechanism of defence against gastrointestinal and oral pathogens in man and animals (Green, 1995; Duncan et al. 1997). Our results extend these later observations by showing for the first time that daily ingestion of an amount of nitrates that can be found in the normal diet protects against an experimental gastritis by releasing NO in the gastric lumen.

In our experiments, gastric mucosal damage was induced by iodoacetamide, a sulfhydryl blocker that has already
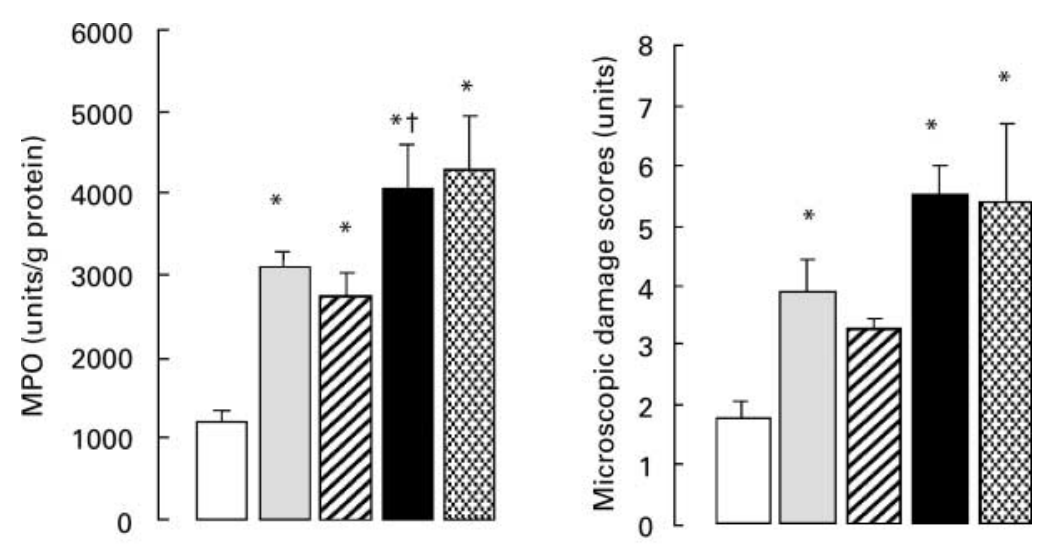

Fig. 6. Effect of $N(G)$-nitro-L-arginine methyl ester (L-NAME) on gastric microscopic damage scores and myeloperoxidase (MPO) activity in iodoacetamide-induced gastritis in rats treated or not with $\mathrm{KNO}_{3}$. Mean values for eight rats per group are shown, with standard errors of the mean being represented by vertical bars. ${ }^{*}$ Mean values were significantly different from that of the control group $(P<0.05)$. $†$ Mean value was significantly different from that of the group treated with L-NAME alone $(P<0.05)$. ( $\square$ ), Control group; ( $\square$ ), iodoacetamide-treated group; (河), L-NAME-treated group; (ם), L-NAME+ iodoacetamide-treated group; (圆), L-NAME+iodoacetamide+ $\mathrm{KNO}_{3}$-treated group. 
been shown to induce diffuse gastritis in rats (Lalich, 1962; Yasin \& Leese, 1970; Karmeli et al. 1996). This agent decreases the concentration of reduced non-protein sulfhydryl compounds in the gastric mucosa (Szabo et al. 1981), and consequently alters the structure of the mucus, which is the first barrier of protection of the gastric mucosa. Thus, in our study, daily administration of iodoacetamide for $7 \mathrm{~d}$ to Wistar rats induced gastric inflammation characterized by a 2.6-fold increase in gastric MPO activity and a 3.5-fold increase in microscopic damage scores. These results agree with those of Karmeli et al. (1996) who showed a 3-fold increase in gastric MPO activity with $7 \mathrm{~d}$ of iodoacetamide treatment. The severity of iodoacetamide-induced gastritis was reduced by a $7 \mathrm{~d}$ treatment with $\mathrm{KNO}_{3}$ at a dose of $250 \mathrm{mg} / \mathrm{kg}$ per d. Daily nitrate consumption in European countries has been estimated to be about $90-120 \mathrm{mg} /$ person (Cornee et al. 1992), corresponding to approximately half of the acceptable daily intake for nitrate in man (World Health Organization, 1962). Taking into account that the acceptable daily intakes for human consumers are calculated by applying a safety factor of 100 to the no-observed effect level determined in animal species (World Health Organization, 1987), it was decided to administer half of the no-observed effect level for nitrates which was estimated at $500 \mathrm{mg} / \mathrm{kg}$ per d, expressed in $\mathrm{KNO}_{3}$ (HP Til, CF Kuper and HE Falke, unpublished results).

$\mathrm{KNO}_{3}$ administration reduced the increase of gastric MPO activity and abolished the tissue damage induced by iodoacetamide. This reduction of gastric inflammation by $\mathrm{KNO}_{3}$ was most probably mediated by $\mathrm{NO}$ since it was reproduced by an NO donor, SNP, and abolished by an NO scavenger, haemoglobin. In our experiments, nitrate was administered intragastrically to rats. In man, ingested nitrates are absorbed from the upper gastrointestinal tract into the plasma and are then concentrated in saliva (Tannenbaum et al. 1976) where they are rapidly reduced to nitrites by anaerobic bacteria (Spiegelhalder et al. 1976; Walters \& Smith, 1981). It has been suggested that this active transport system of nitrates from blood to saliva is lacking in rats (Vittozzi, 1992; Walker, 1994). However, in rats, orally administered nitrate is rapidly absorbed into the bloodstream from the upper small intestine, and the presence of ${ }^{13} \mathrm{~N}$ issued from ${ }^{13} \mathrm{NO}_{\mathrm{x}}^{-}$ administered intravenously has been noted in the saliva of rats (Witter et al. 1979). Our results are in agreement with these studies. Indeed, a significant increase of nitrate levels in both plasma and saliva of rats treated intragastrically with $\mathrm{KNO}_{3}$ was observed; moreover, nitrate levels were identical in the plasma and saliva, confirming the absence of nitrate concentration in the saliva of rats. Even if rats possess nitrate reductase on the tongue ( $\mathrm{Li}$ et al. 1997), significant levels of nitrite in saliva could not be detected. This may be explained by the fact that, in rats, significant nitrite production by tongue bacteria occurs only with very high concentrations of nitrate (Li et al. 1997) and also by the technique used to collect saliva. Pilocarpine induces a high flow of saliva, which probably does not allow a sufficient incubation time to have a significant nitrate reduction by tongue bacteria. However, salivary nitrate reduction is not the only way to obtain nitrites in rats. Indeed, nitrate-reducing flora have been identified in the rat stomach (Bockler $e t$ al. 1983), and the gastric mucosa has been found able to reduce nitrate into nitrite even in germ-free rats (Ward et al. 1986). Finally, the possibility of mediation of the effects of nitrate on gastric mucosa by NO is supported by the fact that nitrite is readily transformed into $\mathrm{NO}$ in the acidic conditions of the stomach (Benjamin et al. 1994).

Some studies have already suggested a protective effect of exogenous NO against gastric mucosal damage (LopezBelmonte et al. 1993; Calatayud et al. 1999; Mourad et al. 2000; Potter \& Hanson, 2000). However, these effects have been shown with NO donors such as glyceryltrinitrate or isoamylnitrite, systemically administered or in in vitro conditions but not after oral ingestion. Our results indicate for the first time a protective action of NO coming from a common dietary component that can be ingested through our daily diet.

Several mechanisms have been proposed to explain the protective role of exogenous $\mathrm{NO}$ on gastric mucosa. The most classical effects attributed to NO on gastric mucosa are the stimulation of blood flow and mucus secretion, and the reduction of acid secretion (Pique et al. 1989; Brown et al. 1993; Kato et al. 1998). These three actions can, by themselves, explain the anti-inflammatory effects of NO at the gastric level. However, other hypotheses can be proposed. Because mast cell activation is known to play a key role in gastric inflammation (Nakajima et al. 1996, 1997) and exogenous NO has been shown to modulate mast cell degranulation (Gaboury et al. 1996; likura et al. 1998), it is possible that dietary NO exerts its effects by stabilizing mast cells. However, this hypothesis requires further investigation, as mast cell degranulation has not been shown yet to be involved in iodoacetamide-induced gastritis. Another possibility could be that exogenous NO inhibited platelet and polymorphonuclear adherence (Radomski et al. 1987; Clancy et al. 1992), thus preventing their activation and the consecutive production of oxidants (Clancy \& Abramson, 1995; Kubes \& Wallace, 1995) whose scavenging function has been shown beneficial in iodoacetamide-induced gastritis (Karmeli et al. 1996). Moreover, recent studies have shown the protective role played by haeme oxygenase-1, an antioxidant enzyme, in gastrointestinal inflammation (Cavicchi et al. 2000; Wang et al. 2000). Since NO donors have been shown to increase haeme oxygenase-1 expression (Hara et al. 1999; Cavicchi et al. 2000), it could be suggested that dietary NO induced antioxidant and anti-inflammatory effects by targeting haeme oxygenase-1 (Polte et al. 2000).

So, considering these possible enzymic modulations of gastric inflammation, an attempt was made to determine the effect of $\mathrm{KNO}_{3}$ treatment on gastric NOS activity. It is usually postulated that during gastrointestinal inflammation, cNOS activity which is responsible for the maintenance of mucosal integrity is diminished while iNOS activity is overexpressed and produces large quantities of NO leading to mucosal injury. It seems however that the modulation of NOS activity during inflammation differs greatly according to the experimental model used and the type of inflammation (Kimura et al. 1997; Nishida et al. 1998; Anton et al. 2000). A significant increase in gastric cNOS activity was observed, but no 
modification of iNOS activity after $7 \mathrm{~d}$ of iodoacetamide treatment. cNOS has been found to account for gastric overproduction of NO in uraemic rats (Mendez et al. 1997), and excessive levels of NO have been shown to reduce gastric cell viability, alter intracellular glutathione homeostasis and increase generation of intracellular oxidants leading to increased gastric cellular injury (Wakulich \& Tepperman, 1997). Moreover, the overexpression of cNOS in portal hypertensive rats is probably responsible for the increased susceptibility of the gastric mucosa to damage (Ohta et al. 1997). Then, chronic administration of iodoacetamide could exacerbate the activation of gastric cNOS leading to an overproduction of $\mathrm{NO}$, and then to deleterious effects on the gastric mucosa. Interestingly, $\mathrm{KNO}_{3}$ treatment abolished the increase in gastric cNOS activity induced by iodoacetamide, suggesting a modulator role of exogenous NO on NOS. A negative feedback of NO on NOS activity has already been shown on cNOS and iNOS enzymes (Griscavage et al. 1993; Rengasamy \& Johns, 1993), suggesting that the effect afforded by $\mathrm{KNO}_{3}$ may also be relevant in gastric inflammation where iNOS activity is increased leading to subsequent NO overproduction such as in Helicobacter pylori-induced gastritis in human subjects (Franco et al. 1999; Fu et al. 1999).

So efforts were made to identify interrelations between NOS and dietary NO by using L-NAME, an NOS isoform non-selective inhibitor. L-NAME treatment for $7 \mathrm{~d}$ increased gastric MPO activity. This pro-inflammatory effect of L-NAME, already described in the small intestine (Miller et al. 1994), unveils a tonic action of NO in the maintenance of gastric mucosa integrity. L-NAME associated with iodoacetamide induced a greater inflammation than L-NAME given alone. This is in agreement with other studies showing that L-NAME aggravates gastric lesions induced by ethanol (Nahavandi et al. 1999), stress (Qiu et al. 1996) or pylorus ligation (Dixit et al. 1999). Exogenous NO brought in by $\mathrm{KNO}_{3}$ was unable to reduce inflammation induced by iodoacetamide associated with L-NAME. This indicates that exogenous NO can protect the gastric mucosa only in the presence of endogenous $\mathrm{NO}$ production.

In conclusion, dietary nitrates exert a protective action on the rat gastric mucosa by producing $\mathrm{NO}$, which can be considered as a complement of endogenous NO. These results confirm the potential therapeutic role of dietary nitrate in human health and highlight the necessity to reconsider its role in our diet.

\section{Acknowledgements}

This work was supported by Institut National de la Recherche Agronomique and by a research award (to M. L.) from Guigoz, Nestlé Santé, France. Part of this work was presented at the 2000 Digestive Disease Week, San Diego, California (Larauche et al. 2000).

\section{References}

Akiba Y, Nakamura M, Mori M, Suzuki H, Oda M, Kimura H, Miura S, Tsuchiya M \& Ishii H (1998) Inhibition of inducible nitric oxide synthase delays gastric ulcer healing in the rat. Journal of Clinical Gastroenterology 27, S64-S73.

Anton PM, Theodorou V, Bertrand V, Eutamene H, Aussenac T, Feyt N, Fioramonti J \& Buéno L (2000) Chronic ingestion of a potential food contaminant induces gastrointestinal inflammation in rats: role of nitric oxide and mast cells. Digestive Diseases and Sciences 45, 1842-1849.

Benjamin N, O'Driscoll F, Dougall H, Duncan C, Smith L, Golden M \& McKenzie H (1994) Stomach NO synthesis. Nature 368, 502.

Bockler R, Meyer H \& Schlag P (1983) An experimental study on bacterial colonization, nitrite and nitrosamine production in the operated stomach. Journal of Cancer Research and Clinical Oncology 105, 62-66.

Bradley PP, Priebat DA, Christensen RD \& Rothstein G (1982) Measurement of cutaneous inflammation: estimation of neutrophil content with an enzyme marker. Journal of Investigative Dermatology 78, 206-209.

Brown JF, Keates AC, Hanson PJ \& Whittle BJ (1993) Nitric oxide generators and cGMP stimulate mucus secretion by rat gastric mucosal cells. American Journal of Physiology 265, G418-G422.

Brown JF, Tepperman BL, Hanson PJ \& Whittle BJ (1994) Lipopolysaccharide induces $\mathrm{Ca}(2+)$-independent nitric oxide synthase activity in rat gastric mucosal cells. European Journal of Pharmacology 292, 111-114.

Bruning-Fann CS \& Kaneene JB (1993) The effects of nitrate, nitrite and $\mathrm{N}$-nitroso compounds on human health: a review. Veterinary and Human Toxicology 35, 521-538.

Bush PA, Gonzalez NE, Griscavage JM \& Ignarro LJ (1992) Nitric oxide synthase from cerebellum catalyzes the formation of equimolar quantities of nitric oxide and citrulline from L-arginine. Biochemical and Biophysical Research Communications 185, 960-966.

Calatayud S, Sanz MJ, Canet A, Bello R, de Rojas FD \& Esplugues JV (1999) Mechanisms of gastroprotection by transdermal nitroglycerin in the rat. British Journal of Pharmacology 127, $1111-1118$.

Cavicchi M, Gibbs L \& Whittle BJR (2000) Inhibition of inducible nitric oxide synthase in the human intestinal epithelial cell line, DLD-1, by the inducers of heme oxygenase 1 , bismuth salts, heme, and nitric oxide donors. Gut 47, 771-778.

Clancy RM \& Abramson SB (1995) Nitric oxide: a novel mediator of inflammation. Proceedings of the Society for Experimental Biology and Medicine 210, 93-101.

Clancy RM, Leszczynska-Piziak J \& Abramson SB (1992) Nitric oxide, an endothelial cell relaxation factor, inhibits neutrophil superoxide anion production via a direct action on the NADPH oxidase. Journal of Clinical Investigation 90, $1116-1121$.

Cornee J, Lairon D, Velema J, Guyader M \& Berthezene P (1992) An estimate of nitrate, nitrite and $\mathrm{N}$-nitrosodimethylamine concentrations in French food products or food groups. Sciences des Aliments 12, 155-197.

Craun GF, Greathouse DG \& Gunderson DH (1981) Methaemoglobin levels in young children consuming high nitrate well water in the United States. International Journal of Epidemiology 10, 309-317.

Dich J, Järvinen R, Knekt P \& Penttila PL (1996) Dietary intakes of nitrate, nitrite and NDMA in the Finnish Mobile Clinic Health Examination Survey. Food Additives and Contaminants 13, 541-552.

Dixit C, Rastogi L \& Dikshit M (1999) Effect of nitric oxide modulators on pylorus-ligation-induced ulcers in the rat. Pharmacological Research 39, 33-39.

Duncan C, Dougall H, Johnston P, Green S, Brogan R, Leifert C, Smith L, Golden M \& Benjamin N (1995) Chemical generation 
of nitric oxide in the mouth from the enterosalivary circulation of dietary nitrate. Nature Medicine 1, 546-551.

Duncan C, Li H, Dykhuizen R, Frazer R, Johnston P, MacKnight G, Smith L, Lamza K, McKenzie H, Batt L, Kelly D, Golden M, Benjamin N \& Leifert C (1997) Protection against oral and gastrointestinal diseases: importance of dietary nitrate intake, oral nitrate reduction and enterosalivary nitrate circulation. Comparative Biochemistry and Physiology 118A, 939-948.

Dykhuizen RS, Frazer R, Duncan C, Smith CC, Golden M, Benjamin N \& Leifert C (1996) Antimicrobial effect of acidified nitrite on gut pathogens: importance of dietary nitrate in host defense. Antimicrobial Agents and Chemotherapy 40, $1422-1425$.

Fabia R, Ar'Rajab A, Johansson ML, Willen R, Andersson R, Molin G \& Bengmark S (1993) The effect of exogenous administration of Lactobacillus reuteri R2LC and oat fiber on acetic acid-induced colitis in the rat. Scandinavian Journal of Gastroenterology 28, 155-162.

Fargeas MJ, Theodorou V, Weirich B, Fioramonti J \& Buéno L (1996) Decrease in sensitization rate and intestinal anaphylactic response after nitric oxide synthase inhibition in a food hypersensitivity model. Gut 38, 598-602.

Franco L, Talamini G, Carra G \& Doria D (1999) Expression of COX-1, COX-2, and inducible nitric oxide synthase protein in human gastric antrum with Helicobacter pylori infection. Prostaglandins and Other Lipid Mediators 58, 9-17.

Fu S, Ramanujam KS, Wong A, Fantry GT, Drachenberg CB, James SP, Meltzer SJ \& Wilson KT (1999) Increased expression and cellular localization of inducible nitric oxide synthase and cyclooxygenase 2 in Helicobacter pylori gastritis. Gastroenterology 116, 1319-1329.

Gaboury JP, Niu XF \& Kubes P (1996) Nitric oxide inhibits numerous features of mast cell-induced inflammation. Circulation 93, 318-326.

Green SJ (1995) Nitric oxide in mucosal immunity. Nature Medicine 1, 515-517.

Griscavage JM, Rogers NE, Sherman MP \& Ignarro LJ (1993) Inducible nitric oxide synthase from a rat alveolar macrophage cell line is inhibited by nitric oxide. Journal of Immunology 151, 6329-6337.

Grisham MB, Johnson GG, Gautreaux MD \& Berg RD (1995) Measurement of nitrate and nitrite in extracellular fluids: a window to systemic nitric oxide metabolism. Methods 7, 84-90.

Gurbuz V, Alican I, Berrak, Yegen C, Bozkurt A, Oktar B, Haklar G, Yuksel M \& Kurtel H (1999) Role of nitric oxide in indomethacin-induced gastric mucosal dysfunction in the rat. Experimental Physiology 84, 319-332.

Hara E, Takahashi K, Takeda K, Nakayama M, Yoshizawa M, Fujita H, Shirato K \& Shibahara S (1999) Induction of heme oxygenase- 1 as a response in sensing the signals evoked by distinct nitric oxide donors. Biochemical Pharmacology 58, 227-236.

Iikura M, Takaishi T, Hirai K, Yamada H, Iida M, Koshino T \& Morita Y (1998) Exogenous nitric oxide regulates the degranulation of human basophils and rat peritoneal mast cells. International Archives of Allergy and Applied Immunology 115, 129-136.

Karmeli F, Okon E \& Rachmilewitz D (1996) Sulfhydryl blockerinduced gastric damage is ameliorated by scavenging of free radicals. Gut 38, 826-831.

Kato S, Kitamura M, Korolkiewicz RP \& Takeuchi K (1998) Role of nitric oxide in regulation of gastric acid secretion in rats: effects of NO donors and NO synthase inhibitor. British Journal of Pharmacology 123, 839-846.

Kimura H, Miura S, Shigematsu T, Ohkubo N, Tsuzuki Y, Kurose I, Higuchi H, Akiba Y, Hokari R, Hirokawa M,
Serizawa H \& Ishii H (1997) Increased nitric oxide production and inducible nitric oxide synthase activity in colonic mucosa of patients with active ulcerative colitis and Crohn's disease. Digestive Diseases and Sciences 42, 1047-1054.

Kitagawa H, Takeda F \& Kohei H (1990) Effect of endotheliumderived-relaxing factor on the gastric lesion induced by $\mathrm{HCl}$ in rats. Journal of Pharmacological and Experimental Therapeutics 253, 1133-1137.

Konturek SK \& Konturek PC (1995) Role of nitric oxide in the digestive system. Digestion 56, 1-13.

Kubes P \& Wallace JL (1995) Nitric oxide as a mediator of gastrointestinal injury? - Say it ain't so. Mediators of Inflammation 4, 397-405.

Lalich JJ (1962) Iodoacetamide-induced gastric ulcer in rats. Proceedings of the Society for Experimental Biology and Medicine 109, 905-908.

Lamarque D \& Whittle BJR (1995) Role of oxygen-derived metabolites in the rat gastric mucosal injury induced by nitric oxide donors. European Journal of Pharmacology 277, 187-194.

Larauche M, Anton P, Fioramonti J, Garcia-Villar R, Theodorou V \& Buéno L (2000) Gastroenterology 118, A793.

Li H, Duncan C, Townend J, Killham K, Smith LM, Johnston P, Dykhuizen R, Kelly D, Golden M, Benjamin N \& Leifert C (1997) Nitrate-reducing bacteria on rat tongues. Applied and Environmental Microbiology 63, 924-930.

Lopez-Belmonte J, Whittle BJR \& Moncada S (1993) The actions of nitric oxide donors in the prevention or induction of injury to the rat gastric mucosa. British Journal of Pharmacology 108, $73-78$.

McCafferty DM, Mudgett JS, Swain MG \& Kubes P (1997) Inducible nitric oxide synthase plays a critical role in resolving intestinal inflammation. Gastroenterology 112, 1022-1027.

McKnight GM, Smith LM, Drummond RS, Duncan CW, Golden M \& Benjamin N (1997) Chemical synthesis of nitric oxide in the stomach from dietary nitrate in humans. Gut $\mathbf{4 0}$, $211-214$

MacNaughton WK, Cirino G \& Wallace JL (1989) Endotheliumderived relaxing factor (nitric oxide) has protective actions in the stomach. Life Science 45, 1869-1876.

Meah MN, Harrison N \& Davies A (1994) Nitrate and nitrite in foods and the diet. Food Additives and Contaminants 11, 519-532.

Mendez A, Fernandez M, Barrios Y, Lopez-Coviella I, GonzalesMora JL, Del Rivero M, Salido E, Bosch J \& Quintero E (1997) Constitutive NOS isoforms account for gastric mucosal NO overproduction in uremic rats. American Journal of Physiology 272, G894-G901.

Miller MJ, Munshi UK, Sadowska-Krowicka H, Kakkis JL, Zhang XJ, Eloby-Childress S \& Clark DA (1994) Inhibition of calcium-dependent nitric oxide synthase causes ileitis and leukocytosis in guinea pigs. Digestive Diseases and Sciences 39, $1185-1192$.

Moncada S, Palmer RMJ \& Higgs EA (1991) Nitric oxide: physiology, pathophysiology, and pharmacology. Pharmacological Reviews 43, 109-142.

Mourad FH, Khuri M, Shouaib F \& Nassar CF (2000) Protective effect of the nitric oxide donor molsidomine on indomethacin and aspirin-induced gastric injury in rats. European Journal of Gastroenterology and Hepatology 12, 81-84.

Nahavandi A, Dehpour AR, Mani AR, Homayounfar H \& Abdoli A (1999) $\mathrm{N}^{\mathrm{G}}$-nitro-L-arginine methylester is protective against ethanol-induced gastric damage in cholestatic rats. European Journal of Pharmacology 370, 283-286.

Nakajima S, Arizono N, Hattori T \& Bamba T (1996) Increase in mucosal and connective tissue-type mast cells in the stomach with acetic acid-induced ulcer in rats. Acta 
Pathologica, Microbiologica et Immunologica Scandinavica 104, 19-29.

Nakajima S, Krishnan B, Ota H, Segura AM, Hattori T, Graham DY \& Genta RM (1997) Mast cells involvement in gastritis with or without Helicobacter pylori infection. Gastroenterology 113, 746-754.

Nishida K, Ohta Y \& Ishiguro I (1998) Changes in nitric oxide production with lesion development in the gastric mucosa of rats with water immersion restraint stress. Research Communications in Molecular Pathology and Pharmacology 100, 201-212.

Ohta H, Tanoue K, Tarnawski AS, Pai R, Itani RM, Sander FC, Sugimachi K \& Sarfeh IJ (1997) Overexpressed nitric oxide synthase in portal-hypertensive stomach of rat: a key to increased susceptibility to damage? Gastroenterology 112, 1920-1930.

Pique JM, Whittle BJ \& Esplugues JV (1989) The vasodilator role of endogenous nitric oxide in the rat gastric microcirculation. European Journal of Pharmacology 174, 293-296.

Polte T, Abate A, Dennery PA \& Schroder H (2000) Heme oxygenase- 1 is a cGMP-inducible endothelial protein and mediates the cytoprotective action of nitric oxide. Arteriosclerosis, Thrombosis and Vascular Biology 20, 1209-1215.

Potter CL \& Hanson PJ (2000) Exogenous nitric oxide inhibits apoptosis in guinea pig gastric mucous cells. Gut 46, 156-162.

Qiu BS, Pfeiffer CJ \& Cho CH (1996) Effects of chronic nitric oxide synthase inhibition in cold-restraint and ethanol-induced gastric mucosal damage in rats. Digestion 57, 60-66.

Rachmilewitz D, Karmeli F, Eliakim R, Stalnikowicz R, Ackerman Z, Amir G \& Stamler JS (1994) Enhanced gastric nitric oxide synthase activity in duodenal ulcer patients. Gut 35, 1394-1397.

Radomski MW, Palmer RM \& Moncada S (1987) Endogenous nitric oxide inhibits human platelet adhesion to vascular endothelium. Lancet ii, 1057-1058.

Rengasamy A \& Johns RA (1993) Regulation of nitric oxide synthase by nitric oxide. Molecular Pharmacology 44, 124-128.

Rouzade ML, Anton P, Fioramonti J, Garcia-Villar R, Theodorou V \& Buéno L (1999) Reduction of the nociceptive response to gastric distension by nitrate ingestion in rats. Alimentary Pharmacology and Therapeutics 13, 1235-1241.

Spiegelhalder B, Eisenbrand G \& Preussman R (1976) Influence of dietary nitrate on nitrite content of human saliva: possible relevance to in vivo formation of N-nitroso compounds. Food and Cosmetics Toxicology 14, 545-548.

Szabo S, Trier JS \& Frankel PW (1981) Sulfhydryl compounds may mediate gastric cytoprotection. Science 214, 200-202.
Tannenbaum SR, Weisman M \& Fett D (1976) The effect of nitrate intake on nitrite formation in human saliva. Food and Cosmetics Toxicology 14, 549-552.

Tepperman BL \& Soper BD (1994) Nitric oxide synthase induction and cytoprotection of rat gastric mucosa from injury by ethanol. Canadian Journal of Physiology and Pharmacology 72, 1308-1312.

Vittozzi L (1992) Toxicology of nitrates and nitrites. Food Additives and Contaminants 9, 579-585.

Wakulich CA \& Tepperman BL (1997) Role of glutathione in nitric oxide-mediated injury to rat gastric mucosal cells. European Journal of Pharmacology 319, 333-341.

Walker R (1994) The conversion of nitrate into nitrite in several animal species and man. In Health Aspects of Nitrate and its Metabolites (Particularly Nitrite), pp. 115-123. Proceedings of an International Workshop, Bilthoven (Netherlands), pp. 115-123. Strasbourg, France: Council of Europe Press.

Walters CL \& Smith PLR (1981) The effect of water-borne nitrate on salivary nitrite. Food and Chemical Toxicology 19, 297-302.

Wang WP, Guo X, Koo MWL \& Cho CH (2000) The protective effect of heme oxygenase-1 induction on the experimental colitis induced by trinitrobenzene sulfonic acid in rats. Gastroenterology 118, A579.

Ward FW, Coates ME \& Walker R (1986) Nitrate reduction, gastrointestinal $\mathrm{pH}$ and $\mathrm{N}$-nitrosation in gnotobiotic and conventional rats. Food and Chemical Toxicology 24, 17-22.

Wei XQ, Charles IG, Smith A, Ure J, Feng GJ, Huang FP, Xu D, Muller W, Moncada S \& Liew FY (1995) Altered immune responses in mice lacking inducible nitric oxide synthase. Nature 375, 408-411.

Witter JP, Balish E \& Gatley SJ (1979) Distribution of nitrogen-13 from labeled nitrate and nitrites in germfree and conventionalflora rats. Applied and Environmental Microbiology 38, $870-878$.

World Health Organization (1962) Evaluation of the toxicity of a number of antimicrobials and antioxidants (Sixth report of the Joint FAO/WHO Expert Committee on Food Additives). WHO Technical Report Series no. 228, pp. 73-76. Geneva, Switzerland: WHO.

World Health Organization (1987) Principles for the safety assessment of food additives and contaminants in food. WHO Environmental Health Criteria no. 70. Geneva, Switzerland: WHO.

Yasin R \& Leese CL (1970) The production of chronic gastritis and ulceration in the glandular stomach of rats by iodoacetamide. European Journal of Cancer 6, 425-432. 